\title{
ITPA GENE VARIANT MAY PROTECT AGAINST ANEMIA INDUCED DURING PEGYLATED INTERFERON ALFA AND RIBAVIRIN COMBINATION TREATMENT IN UKRAINIAN PATIENTS WITH CHRONIC HEPATITIS C
}

\author{
A. KUCHERENKO ${ }^{1,2}$, V. PAMPUKHA ${ }^{1}$, I. BOBROVA ${ }^{3}$, L. MOROZ ${ }^{4}$, L. LIVSHITS ${ }^{1}$ \\ ${ }^{1}$ Institute of Molecular Biology and Genetics NAS of Ukraine, Kyiv \\ E-mail: kucherenko.a.m@gmail.com \\ ${ }^{2}$ Taras Shevchenko National University of Kyiv \\ ${ }^{3}$ Ukrainian Treatment and Diagnostic Center, Kyiv \\ ${ }^{4}$ National Pirogov Memorial Medical University, Vinnytsya
}

\begin{abstract}
The aim of this study was to clarify the association between the inosine triphosphate pyrophosphatase (ITPA) gene variants and PEG-IFNa/RBV combination treatment induced anemia in chronic hepatitis $\mathrm{C}(\mathrm{CHC})$ Ukrainian patients. The data were collected from $80 \mathrm{CHC}$ patients with $\mathrm{HCV}$ genotype 1 infection. All study participants received standard doses of PEG-IFN $\alpha$ and RBV. According to the Hb level changes patients were distributed into: case group -42 patients with combination treatment induced anemia, and control group - 38 patients with no signs of anemia. Genotyping for ITPA gene rs 1127354 and rs 7270101 variants was performed using PCR followed by RFLP assay. Fisher's exact test was used to estimate the difference in genotype and allelic distribution. Distribution of rs 7270101 genotypes was not significantly different between groups of $\mathrm{CHC}$ patients with $R B V$-induced anemia and without it. The frequency of rs $1127354 \mathrm{~A}$ allele carriers was significantly higher $(P<$ $<0,05)$ in group of $C H C$ patients without anemia $(23,7 \%)$ comparing to the group of patients with anemia $(7,3 \%)$. The respective allele frequency in control group $(13,2 \%)$ was almost 3-fold higher $(P<0,05)$ comparing to the case group (4,9\%). Significant association of ITPA gene rs 1127354 with protection against $R B V$-induced hemolytic anemia was found in Ukrainian patients with CHC infection. Rs 1127354 variant may assist as a pharmacogenetic marker in $\mathrm{HCV}$ antiviral therapy correction for side effect avoidance.
\end{abstract}

Key words: chronic hepatitis C, ITPA gene, side effects, hemolytic anemia, pharmacogenetics.

Introduction. An estimated number of 150 million people is currently affected by hepatitis $\mathrm{C}$ virus (HCV) infection, which corresponds to $2.35 \%$ of the world population [1]. In $70-80 \%$ cases a primary HCV infection develops into chronic infection with its complications of liver cirrhosis and/ or hepatocellular carcinoma [2]. Current approach

(C) A. KUCHERENKO, V. PAMPUKHA, I. BOBROVA, L. MOROZ, L. LIVSHITS, 2015

to chronic hepatitis $\mathrm{C}(\mathrm{CHC})$ antiviral treatment includes pegylated interferon alfa (PEG-IFN) and ribavirin (RBV) combination therapy [3]. However, despite its advances in the treatment of $\mathrm{CHC}$, combination therapy is also associated with various toxic affects like psychiatric illness, constitutional side effects, and cytopenias [4]. The most common side effect of RBV treatment is hemolytic anemia which is also the major cause for RBV dose reduction [5]. Studies report that those patients receiving less than $60 \%$ of the initially selected RBV dose have a lower response rate and a higher relapse rate comparing to patients receiving a higher dose [6].

In recent years, genome-wide association studies (GWASs) have demonstrated a strong association between single nucleotide polymorphisms (SNP) of the inosine triphosphate pyrophosphatase (ITPA) gene and RBV-induced anemia in a cohort of patients infected with HCV genotype 1 [7]. The identified SNP was found on chromosome 20: rs1127354 (missense variant in exon 2, 94C $>$ A mutation) and rs7270101 (splicing-altering SNP in intron 2, IVS2 + 21A > C mutation) [8]. Both rs1127354 and rs7270101 functional variants are known to cause missplicing of exons 2 and 3 causing the synthesis of protein with reduced enzyme activity [9] and consequently may be associated with protective phenotype against RBV-induced anemia.

Although CHC is widespread in Ukraine, it has not been spotlighted from the standpoint of host genetic studies. The motivation to conduct this study was to clarify for the first time in CHC Ukrainian patients the association between the variants of the ITPA gene and PEG-IFN $\alpha$ and RBV combination treatment induced anemia.

Methods. The data of this study were collected from 80 Ukrainian CHC patients (43 females, 37 
males). All were positive for HCV RNA for more than 6 months and mono-infected with chronic hepatitis $\mathrm{C}$ with no evidence of HIV or hepatitis $\mathrm{B}$ infection. All participants were treatment-naive patients with no evidence of the presence of any associated liver diseases other than chronic viral hepatitis C. The pretreatment HCV RNA level was detected by quantitative real time polymerase chain reaction (PCR) technique with a lower limit of detection of $300 \mathrm{IU} / \mathrm{mL}$. The high viral load (RNA $\mathrm{HCV}>600000 \mathrm{IU} / \mathrm{ml}$ ) was observed in 46,25\% of patients. Qualitative PCR by TaqMan assay was used for detection of viral load at weeks 4,12 , 24 and 48 . HCV genotype determination was by sequence determination in the $5^{\prime}$-nonstructual region of the $\mathrm{HCV}$ genome followed by phylogenetic analysis. In all the patients enrolled in this study the HCV genotype 1 infection was detected.

All patients underwent a pretreatment liver biopsy in order to evaluate liver disease activity and fibrosis stage which were scored by the Metavir scoring system. Patients with fibrosis stage of F4 and higher were excluded from the study as they are more prone to cytopenic syndrome regardless of treatment. All study participants received standard doses of the combination treatment of PEG-IFN $\alpha$ and RBV. In the first week of treatment, all patients were given the fully recommended dosages of RBV. During the course of treatment $\mathrm{Hb}$ level measurements were performed at least 6-12 times (every 2-4 weeks) for every patient. The steady decrease of $\mathrm{Hb}$ level below $130 \mathrm{~g} / 1$ for men and $120 \mathrm{~g} / 1$ for women was considered as anemia. According to the $\mathrm{Hb}$ level changes all the patients were distributed into two groups: case group -42 patients with combination treatment induced anemia, and control group - 38 patients with no signs of anemia. Additionally, a group of 100 unrelated healthy donors from general population of Ukraine (50 females, 50 males) was genotyped for studied polymorphisms. Informed consent was obtained from all participants prior to the collection and storage of blood samples for ITPA polymorphism testing. The study has been approved by The Bioethical Committee of Institute of Molecular Biology and Genetics of NAS of Ukraine.

The protocol specified a treatment duration of 48 weeks. The majority of patients $(55,0 \%)$ received PEG-IFN $\alpha 2 \mathrm{a}$ (Pegasys) at a dose of $180 \mu \mathrm{g}$ per week and $45,0 \%$ received PEG-IFNa2b (Pegintron) as

Table 1. Genotype and allele distribution of ITPA gene rs1127354 and rs7270101 variants in studied groups

\begin{tabular}{c|c|c|c|c|c|c}
\hline \multirow{2}{*}{$\begin{array}{c}\text { Genotype/ } \\
\text { Allele }\end{array}$} & \multicolumn{2}{|c|}{$\begin{array}{c}\text { Anemia } \\
\text { group }\end{array}$} & \multicolumn{2}{c|}{$\begin{array}{c}\text { Control } \\
\text { group }\end{array}$} & \multicolumn{2}{c}{$\begin{array}{c}\text { Population } \\
\text { group }\end{array}$} \\
\cline { 2 - 7 } & $n$ & $\%$ & $n$ & $\%$ & $n$ & $\%$ \\
\hline
\end{tabular}

rs1127354

$\begin{array}{ccccccc}\text { Genotype } & & & & & \\ \text { C/C } & 38 & 92,7 & 29 & 76,3 & 81 & 81,0 \\ \text { C/A } & 2 & 4,9 & 8 & 21,1 & 17 & 17,0 \\ \text { A/A } & 1 & 2,4 & 1 & 2,6 & 2 & 2,0 \\ \text { Allele } & & & & & & \\ \text { C } & & 95,1 & & 86,8 & & 89,5 \\ \text { T } & & 4,9 & 13,2 & & 10,5 \\ & & \text { rs } 7270101 & & \end{array}$

\begin{tabular}{ccccccc} 
Genotype & & & & & & \\
A/A & 34 & 81,0 & 31 & 81,6 & 85 & 85,0 \\
A/C & 8 & 19,1 & 7 & 18,4 & 14 & 14,0 \\
C/C & 0 & 0,0 & 0 & 0,0 & 1 & 1,0 \\
Allele & & & & & & \\
A & & 90,5 & & 90,8 & & 92,0 \\
C & & 9,5 & & 9,2 & & 8,0 \\
\hline
\end{tabular}

Table 2. Comparative analysis of rs1127354 and rs7270101 minor allele population frequencies

\begin{tabular}{lcc|c|c}
\hline \multicolumn{1}{c|}{ Population } & rs1127354 MIF & $\mathrm{p}^{*}$ & rs7270101 MIF & $\mathrm{p}^{*}$ \\
\hline European & 0,078 & 0,277 & 0,12 & 0,134 \\
Eastern Asian & 0,131 & 0,404 & 0,0 & 0,8821 \\
African & 0,047 & 0,009 & 0,087 & 0,9371 \\
Ad Mixed American & 0,052 & 0,03 & 0,075 & 0,08 \\
Ukrainian & 0,105 & & \\
\hline
\end{tabular}

Note. $\mathrm{p}$ - Fisher's exact test results (2-tailed p-value). MIF - minor allele frequency. * Calculated between respective population and Ukrainian population. 
a subcutaneous injection at a dose of $1.5 \mu \mathrm{g} / \mathrm{kg}$ per week. All patients received a $15 \mathrm{mg} / \mathrm{kg}$ daily oral dose of RBV (Copegus or Rebetol). However, the study was designed with a futility-stopping rule that would halt the trial if there was $<2 \log 10 \mathrm{HCV}$ RNA decline at week 12 or persistent viremia at week 24 .

DNA from $80 \mathrm{CHC}$ patients and 100 healthy donors from general population of Ukraine was extracted by standard method using proteinase $\mathrm{K}$ with the following chlorophorm extraction. ITPA gene DNA sequence was amplified by routine PCR using mismatched primers to create an $X m n I$ restriction sites as described elsewhere [10].

Statistical analysis has been performed using GenePop and OpenEpi statistical packages [11, 12] Fisher's exact test was used to estimate the difference in genotype and allelic distribution. A P-value of less than 0.05 was regarded as significant.

Results. The genotype and allele distributions for rs1127354 and rs7270101 variants are presented in the table 1. Genotype distribution for both studied polymorphisms in three studied groups was according to Hardy-Weinberg equilibrium. Comparative analysis of previously reported rs 1127354 and rs7270101 variant minor allele population frequencies [13] and results obtained in this study is shown in table 2.

There were no differences found in rs7270101 variant allele distribution reported for super populations, which are part of 1000 Genomes project [13] and the ones revealed in this study. On the other hand, rs1127354 variant allele distribution in Ukrainian population was significantly different compared to African and Ad Mixed American populations.

Genotype and allele distributions of rs1127354 and rs7270101 did not differ between population group and groups of patients with or without anemia. Distribution of rs7270101 genotypes was not significantly different between groups of $\mathrm{CHC}$ patients with RBV-induced anemia and without it. The significant difference was observed in rs1127354 allele and genotype distributions between studied groups of patients. The rs1127354 A allele carriers frequency was significantly higher $(\mathrm{p}=$ $=0,04)$ in group of $\mathrm{CHC}$ patients without anemia $(23,7 \%)$ comparing to the group of patients with anemia $(7,3 \%)$. The respective allele frequency in group of $\mathrm{CHC}$ patients without anemia $(13,2 \%)$ was more than twofold higher comparing to the case group $(4,9 \%)$.
Discussion. To our knowledge, this is the first study to assess the impact of the rs1127354 and rs7270101 ITPA genotypes on the RBV-induced anemia development in Ukrainian patients with chronic hepatitis $\mathrm{C}$ infection, regardless of the outcome of treatment. Several previous studies have also demonstrated the protective benefit of the rs1127354 allele A against RBV-induced anemia during the first 12 weeks of treatment $[14,15]$. The protective impact of ITPA deficiency is supposed to be as follows. RBVinduced anemia mechanism includes an oxidative damage to erythrocyte membranes and extravascular erythrophagocytosis provoked by accumulation of the RBV metabolite - triphosphorylated RBV [16]. ITPA deficiency causes a strong accumulation of inosine triphosphate (ITP) which competes with triphosphorylated RBV in erythrocytes and protects cells from the hemolytic effects [17]. Anemia is reported to be a major cause of RBV dose reduction, which in $10-14 \%$ of $\mathrm{HCV}$-infected patients extends to early withdrawal from treatment in the first 12 weeks [5]. Taking into the account our results as well as results obtained in other studies, RBV dose reduction in the early weeks of treatment is evidently necessary for patients with rs1127354 CC.

In conclusion, the significant association of ITPA gene rs1127354 with protection against RBV-induced hemolytic anemia has been found in Ukrainian patients with chronic hepatitis $\mathrm{C}$ infection. ITPA genotyping, may assist in HCV antiviral therapy correction in patients, particularly ones at high risk for hemolytic anemia or anemia-related morbidity.

This work was supported by the National Academy of Sciences of Ukraine [grant № 0112U002108]; the State of Ukraine [grant № 0113U006253] and the President of Ukraine grant for talented youth.

АЛЛЕЛЬНЫЙ ВАРИАНТ ГЕНА ІТРА МОЖЕТ ЗАЩИЩАТЬ ПАЦИЕНТОВ С ХРОНИЧЕСКИМ ГЕПАТИТОМ $C$ ИЗ УКРАИНЫ ПРОТИВ АНЕМИИ, ИНДУЦИРОВАННОЙ КОМБИНИРОВАННОЙ ТЕРАПИЕЙ ПЕГИЛИРОВАННЫМ ИНТЕРФЕРОНОМ И РИБАВИРИНОМ

А.М. Кучеренко, В.Н. Пампуха, И.А. Боброва, Л.В. Мороз, Л.А. Лившии

Целью настоящего исследования было изучить ассоциацию аллельных вариантов гена инозин трифосфат пирофосфатазы (ITPA) с анемией, индуцированной комбинированной терапией пегилирован- 
ным интерфероном (PEG-IFN $\alpha$ ) и рибавирином (RBV) у пациентов из Украины с хроническим гепатитом C (ХГС). Данные собраны у 80 пациентов с ХГС, которые имели первый генотип вируса. Все участники исследования получали стандартные дозы PEG - IFN $\alpha$ и RBV. В соответствии с изменениями уровня гемоглобина пациенты были разделены на исследуемую группу (42 пациента с анемией) и контрольную (38 пациентов без признаков анемии). Генотипирование полиморфных вариантов rs1127354 и rs7270101 гена ITPA проводили с помощью ПЦР с последующим ПДРФ анализом. Распределение генотипов по полиморфному варианту rs7270101 достоверно не отличалось в группе ХГС пациентов с RBV-индуцированной анемией и без нее. Частота носителей аллеля rs1127354 А была выше в группе пациентов с ХГС без анемии $(23,7$ \%) по сравнению с группой пациентов с анемией. Частота соответствующего аллеля в контрольной группе $(13,2 \%)$ была выше, чем в группе пациентов с анемией $(4,9 \%)$ почти втрое. Найдена достоверная ассоциация полиморфного варианта rs1127354 гена ITPA с протекцией против рибавирин-индуцированной гемолитической анемии у пациентов из Украины с ХГС. Полиморфный вариант rs1127354 может служить фармакогенетическим маркером для коррекции противовирусной терапии гепатита С во избежание побочных эффектов.

\section{REFERENCE}

1. Mohd Hanafiah K., Groeger J., Flaxman A.D., Wiersma S.T. Global epidemiology of hepatitis $\mathrm{C}$ virus infection: new estimates of age-specific antibody to HCV seroprevalence // Hepatology. 2013. - 57, № 4. - P. 1333-1342.

2. Lozano R., Naghavi M., Foreman K. et al. Global and regional mortality from 235 causes of death for 20 age groups in 1990 and 2010: a systematic analysis for the Global Burden of Disease Study 2010 // Lancet. - 2012. - 380, № 9859. - P. 2095-2128.

3. Kanda T., Yokosuka O. Pegylated interferon-alfa plus ribavirin therapies for chronic hepatitis $\mathrm{C} / / \mathrm{J}$. Nepal. Med. Ass. - 2011. - 51, № 181. - P. 41-48.

4. Fried M.W., Shiffman M.L., Reddy K.R. et al. Peginterferon alfa-2a plus ribavirin for chronic hepatitis C virus infection // N. Engl. J. Med. 2002. - 347, № 13. - P. 975-982.

5. Takaki S., Tsubota A., Hosaka T. et al. Factors contributing to ribavirin dose reduction due to anemia during interferon alfa $2 \mathrm{~b}$ and ribavirin combination therapy for chronic hepatitis C // J. Gastroenterol. 2004. - 39, № 7. - P. 668-673.

6. Krishnan S.M., Dixit N.M. Ribavirin-induced anemia in hepatitis $\mathrm{C}$ virus patients undergoing combination therapy // PLoS Comput. Biol. - 2011. - 7, № 2. P. e1001072.

7. Tanaka Y., Nishida N., Sugiyama M. et al. Genomewide association of IL28B with response to pegylated interferon-alpha and ribavirin therapy for chronic hepatitis C // Nat. Genet. - 2009. - 41. - P. 11051109.

8. Fellay J., Thompson A.J., Ge D. et al. ITPA gene variants protect against anaemia in patients treated for chronic hepatitis C // Nature. - 2010. - 464. P. 405-408.

9. Arenas M., Duley J., Sumi S. et al. The ITPA c.94C >A and g.IVS2+21A $>C$ sequence variants contribute to missplicing of the ITPA gene // Biochim. biophys. acta. - 2007. - 1772, № 1. - P. 96-102.

10. Melaouhia S., Fékih M., Garat A. et al. Allele frequency of inosine triphosphate pyrophosphatase (ITPA) and thiopurine-S-methyl transferase (TPMT) genes in the Tunisian population // Clin. Res. Hepatol. Gastroenterol. - 2012. - 36, № 2. - P. 178-184.

11. Rousset F. Genepop'007: a complete re-implementation of the genepop software for Windows and Linux // Mol. Ecol. Res. - 2008. - 8, № 1. P. 103-106.

12. Sullivan K.M., Dean A., Soe M.M. OpenEpi: a webbased epidemiologic and statistical calculator for public health // Public Health Rep. - 2009. - 124, № 3. - P. 471-474.

13. 1000 Genomes Project Consortium, Abecasis G.R., Auton A. et al. An integrated map of genetic variation from 1,092 human genomes // Nature. - 2012. 491, № 7422. - P. 56-65.

14. Thompson A.J., Fellay J., Patel K. et al. Variants in the ITPA gene protect against ribavirin-induced hemolytic anemia and decrease the need for ribavirin dose reduction // Gastroenterology. - 2010. - 139, № 4. - P. 1181-1189.

15. Azakami T., Hayes C.N., Sezaki H. et al. Common genetic polymorphism of ITPA gene affects ribavirininduced anemia and effect of peg-interferon plus ribavirin therapy // J. Med. Virol. - 2011. - 83, № 6. - P. 1048-1057.

16. De Franceschi L., Fattovich G., Turrini F. et al. Hemolytic anemia induced by ribavirin therapy in patients with chronic hepatitis $\mathrm{C}$ virus infection: role of membrane oxidative damage // Hepatology. 2000. - 31. - P. 997-1004.

17. Hitomi Y., Cirulli E.T., Fellay J. et al. Inosine triphosphate protects against ribavirin-induced adenosine triphosphate loss by restoring adenylosuccinate synthase function // Gastroenterology. - 2011. 140. - P. 1314-1321. 